\title{
Izbori u Riječkoj županiji i njezini zastupnici na Hrvatskom saboru 1861. godine ${ }^{* *}$
}

Prvi parlamentarni izbori u Riječkoj županiji održani su 1861. godine. Riječka županija birala je pet zastupnika, pa se u radu prikazuje izborni proces na području svih pet kotareva koliko ih je županija imala. Zatim se analizira djelovanje izabranih zastupnika Riječke županije na Saboru 1861., tj. njihova usklađenost s Naputkom koji im je županija izdala, a u kojem se nalaze smjernice za njihovo saborsko djelovanje, ali i drugi saborski rad.

Ključne riječi: saborski izbori, Hrvatski sabor 1861., Riječka županija, saborski zastupnici

\section{Uvod}

Riječka županija formirana je u lipnju 1850. prilikom uspostave nove političke uprave, i to od bivšega Ugarskog primorja, koje je tada ukinuto, i gorskokotarskoga područja, koje je uzeto Zagrebačkoj županiji, tj. prostora do rijeke Kupe. Unatoč tome što je formirana, kao i druge hrvatske županije, zbog reorganizacije županijskoga uređenja u interesu novoga centralističkog sustava nije imala širo$\mathrm{ku}$ unutrašnju autonomiju kako je to bilo u prethodnom razdoblju, a s novom reorganizacijom 1854. samo je formalno postojala. ${ }^{1}$

\footnotetext{
Arijana Kolak Bošnjak, Hrvatski institut za povijest, Opatička 10, 10000 Zagreb, Republika Hrvatska, E-mail adresa: akolak@isp.hr

** Ovaj članak nastao je u sklopu projekta IP-2019-04-5148 MAPPAR (Mapiranje parlamentarnih izbora 1848. - 1918. u Hrvatskoj), koji financira Hrvatska zaklada za znanost.

1 Tomislav Markus, Predstavke županija i gradova Banske Hrvatske: izabrani dokumenti 1861. - 1867. (Zagreb: Dom i svijet, 2002), 20; Dragutin Pavličević, „Županije u Hrvatskoj i Slavoniji u prijelaznom razdoblju od 1848. do 1881.”, u: Hrvatske županije kroz stoljeća, ur. Ivo Goldstein (Zagreb: Školska knjiga, 1996), 77; Milan Smrekar, Priručnik za političku upravnu službu u kraljevinah Hrvatskoj i Sla-
} 
Promjena sustava i povratak ustavnosti u zemljama Habsburške Monarhije najavljeni su Listopadskom diplomom s kraja 1860., čime započinje i obnova županija. Banska konferencija koja je zasjedala od studenog 1860. do siječnja 1861. zaključila je da u Hrvatskoj i Slavoniji treba vratiti ustavne županije i da se ustavno trebaju urediti gradovi te izradila Naputak za privremeno uređenje županija, gradova i općina, a 16. siječnja 1861. potvrdio ga je i vladar. U njemu je iskazana tendencija da se obnovi nekadašnja samouprava županija i gradova, a pravo glasa u županijskim skupštinama određeno je na temelju imovinskoga cenzusa za pojedine profesije i djelatnosti. Granice pojedinih županija bile su prema njemu uglavnom one iz 1848., a za Riječku županiju priznate su one koje je imala u tom trenutku. U Naputku je stajalo i da unutarnju podjelu svojega teritorija na kotareve i općine županije mogu same određivati, ali su odluku morale podnijeti Namjesništvu da bi se službeno i javno proglasile, te da županijske skupštine samostalno biraju svoje činovnike. ${ }^{2}$

Riječka je županija prema Naputku bila podijeljena na dva okružja, vinodolsko i gorsko, pri čemu se gorsko okružje dijelilo na vrbovski, delnički i čabarski kotar, a vinodolsko okružje bilo je jedna cjelina, tj. jedan kotar. Slobodni grad Rijeka i Bakar sa svojim su kotarevima stupili u svoje granice od 1. siječnja 1848. te su bili zasebni municipiji i kao takvi dobili pravo birati vlastite zastupnike za Hrvatski sabor. ${ }^{3}$ U sklopu Riječke županije nalazila su se povlaštena trgovišta Mrkopalj, Ravna Gora i Vrbovsko, koja su bila zasebni municipiji, a zajedno su birala jednoga zastupnika, kao i općine Novi i Bribir, koje su svaka zasebno birale jednoga zastupnika. Ipak, i slobodni kotarevi i povlaštena trgovišta s područja županije imali su pravo sudjelovati u radu riječke županijske skupštine, pa su neki upravo preko nje nastojali izboriti pravo da pošalju veći broj zastupnika na Hrvatski sabor, a riječki gradski odbor odlučio je da nikako neće sudjelovati u poslovima županije jer je smatrao da grad Rijeka sa svojim kotarom ne sačinjava dio novoustrojene Riječke županije te naglašavao da je njegovo zastupstvo samostalno. ${ }^{4}$

S obzirom na to da 1848. Riječka županija nije postojala, u Naputku je posebno definirano njezino poglavarstvo, na čijem je čelu stajao veliki župan, koji je ujedno bio riječki i bakarski civilni kapetan. Uz njega su postojala i dva podžupana, jedan veliki bilježnik s jednim podbilježnikom i arhivarom, koji je ujedno bio

voniji (Zagreb: Tiskom i nakladom Ignjata Granitza, 1899), 14, 19-20; Danilo Klen, ur., Povijest Rijeke (Rijeka: Skupština općine Rijeka; Izdavački centar Rijeka, 1988), 212; Ferdinand Hauptmann, Rijeka: od rimske Tarsatike do Hrvatsko-ugarske nagodbe (Zagreb: Matica hrvatska, 1951), 129.

2 Markus, Predstavke županija i gradova Banske Hrvatske, 26, 97-98; Smrekar, Priručnik za političku upravnu službu, 21-23.

3 Markus, Predstavke županija i gradova Banske Hrvatske, 98; Hrvatska (dalje: HR) - Hrvatski državni arhiv, Zagreb (dalje: HDA) - fond 99 - Riječka županija (dalje: RŽ), kut. 40, br. 58, Izborni red za Sabor 1861., $\$ 2$., $\$ 3$., $\$ 6$.

4 Markus, Predstavke županija i gradova Banske Hrvatske, 100; Hauptmann, Rijeka, 133; HR-HDA99-RŽ, kut. 40, br. 3. 
registrator, zatim jedan županijski odvjetnik, jedan blagajnik i podblagajnik, dva velika sudca i dva kotarska sudca te četiri pristava i drugi. Veliki župan Riječke županije Bartol Zmaić uveden je u svoju čast 19. veljače 1861., a već sutradan ustrojena je i sama županija imenovanjem novih časnika. Podžupanom je postao Ivan Vončina, velikim bilježnikom dr. Ante Starčević, podbilježnikom dr. Marijan Derenčin, velikim županijskim odvjetnikom Faustin Suppé, blagajnikom Ljudevit Ott, velikim sudcima Matija Matković i Mudrovčić, a kotarskim sudcima Erazmo pl. Barčić, Tomo Padavić i Roman Mužević. ${ }^{5}$ S obzirom na to da broj činovnika ne odgovara onome određenom u Naputku, možemo pretpostaviti da je već tada županija mijenjala svoju teritorijalnu podjelu, što je bilo vidljivo i u njezinu zahtjevu da pojedini kotarevi mogu birati više zastupnika za Sabor. Zbog nereda koji su vladali u gradu Rijeci županija je svoj rad morala premjestiti u Bakar, gdje je i ustrojena.

Banska konferencija sazvana je zapravo da napravi pripreme za saziv Hrvatskoga sabora, tj. donese izborni red. Ona je iznijela zahtjev da se Hrvatski sabor sazove što brže, i to prema izbornom redu iz 1848., a naglasila je da se posebna pozornost pri sazivanju Sabora, uz još neke oblasti, treba posvetiti novoustrojenoj Riječkoj županiji, koja 1848 . nije postojala. ${ }^{6}$

Izborni red bio je privremen, a po njemu su izbori provođeni posredno, tj. saborske zastupnike birale su državne i političke ustanove, županije, gradovi, kotarevi, trgovišta i općine.

5 Markus, Predstavke županija i gradova Banske Hrvatske, 99; Irvin Lukežić, Riječki kvartet (Rijeka: Filozofski fakultet Sveučilišta u Rijeci, 2008), 49; „Prva skupština riečke županie”, Pozor (Zagreb), br. 49, 28. 2. 1861., 111 .

6 Hodimir Sirotković, „Izborni red za Sabor od 1861. godine i provođenje izbora”, Rad JAZU, knj. 47 (1967), 213-216; Markus, Predstavke županija i gradova Banske Hrvatske, 39, 94. Za saborske izbore 1861. saborski red iz 1848. bio je reduciran, što znači da u njemu nisu bile zastupljene Vojna krajina i Dalmacija, a unesene su i druge promjene koje su utjecale na to da broj zastupnika za Sabor 1861. bude znatno smanjen u odnosu na onaj iz 1848., konkretno sa 191 na 120. Tijekom zasjedanja broj zastupnika je povećan jer su neke oblasti dobile pravo poslati više zastupnika, a saborskom su se zasjedanju krajem svibnja 1861. pridružili i zastupnici iz Vojne krajine. Ivo Perić, Hrvatski državni sabor 1848. - 2000., sv. 1: 1848. - 1867. (Zagreb: Hrvatski državni sabor; Hrvatski institut za povijest; Dom i svijet, 2000), 227-228.

7 Markus, Predstavke županija i gradova Banske Hrvatske, 39. Izborne jedinice za Hrvatski sabor 1861. imale su osnovu u županijama i gradovima, a izborno pravo priznavalo se određenim samoupravnim tijelima, županijama, slobodnim kraljevskim gradovima i drugim samoupravnim municipijima te kaptolima i konzistorijima, zagrebačkoj Akademiji, a naknadno i krajiškim regimentama. Županijski su zastupnici birani posredno, što znači da su unutar najnižih upravnih jedinica županije, općina ili sudčija, izabirani izbornici koji su birali zastupnika svojega kotara, a svaka županija slala je na Sabor onoliko zastupnika koliko je imala kotareva. Taj sustav razlikovao se od kurijalnoga izbornog sustava prema kojem su birani zastupnici za Dalmatinski i Istarski sabor. On se temeljio na kurijama, razredima u koje su birači bili podijeljeni prema društveno-ekonomskoj pripadnosti, koja je bila vezana uz porezni cenzus. Tako su postojale kurije veleposjednika, gradova, zatim trgovačko-obrtničkih komora i kao porezno „najslabija” kurija seoskih općina. Takav sustav pogodovao je bogatijem i obrazovanijem stanovništvu jer je četvrta kurija, s najbrojnijim biračima, bila podzastupljena. Sirotković, „Izborni red”, 219-222; Filip Hameršak, prir., Mali leksikon hrvatske pravne povijesti (Zagreb, 


\section{Izbori na području Riječke županije}

Prema privremenom izbornom redu, Riječka županija birala je četiri zastupnika. Ban Šokčević 5. ožujka 1861. izdao je naredbu da se proglasi privremeni izborni red, a Riječka županija primila ju je 15. ožujka i proslijedila nižim upravnim jedinicama da bi se izbori proveli na vrijeme. Izbor zastupnika u županijama obavljao se tako da su najprije u svakoj općini ili sudčiji jednoga kotara, tj. distrikta birani, ovisno o veličini sudčije, jedan ili dvojica starješina odnosno gospodara kuće te su oni kao izbornici birali jednoga zastupnika za svoj kotar, a sam izbor nadziralo je županijsko poglavarstvo. U pravilima izbornoga reda stajalo je da se iz izbora kotarskih zastupnika isključuju slobodni kraljevski gradovi, povlaštena trgovišta ili općine koji se nalaze na području nekoga kotara i sami biraju svoje zastupnike za Sabor, a na području Riječke županije to su bila, kako je spomenuto, trgovišta Mrkopalj, Ravna Gora, Vrbovsko te općine Novi i Bribir. ${ }^{8}$

Na području Riječke županije izborna kampanja nije bila žustra, ${ }^{9}$ ali je neki oblik agitacije postojao. Ona se provodila preporukama pojedinaca ili oblasti i njihovim dogovaranjem da se izaberu pojedini kandidati, ali i preko novina, u kojima su se objavljivala imena kandidata za koje je trebalo glasati i o njima se pozitivno pisalo. ${ }^{10}$ Tako je npr. dopisnik Pozora, nahvalivši izabrane riječke županijske časnike riječima: „Za sada mislimo, da boljih naći nije...”, smatrao da bi taj privremeni izbor županijskih časnika mogao vrijediti i za Sabor, tj. da isti časnici budu županijski zastupnici na predstojećem Hrvatskom saboru. Neki od njih zaista su i izabrani za zastupnike Riječke županije. Kad se pak drugi put birao zastupnik vinodolskoga kotara, u pismu koje je županija uputila kotarskoj oblasti predloženo je da se za zastupnike njihova kotara izaberu Ivan Mažuranić i Ante Starčević. ${ }^{11}$ I Starčević je u svojim Uspomenama posvjedočio da su „od stanovite strane predloženi” za saborske zastupnike određeni pojedinci među kojima su

2013), pristup ostvaren 12. 11. 2021., https://www.pravo.unizg.hr/_download/repository/Mali_leksikon_hrvatske_pravne_povijesti\%5B1\%5D.pdf.

$8 \quad$ Izborni red za Sabor 1861., čl. I., \$2., čl. II., \$6., HR-HDA-99-RŽ, kut. 40, br. 58.

9 Za razliku od županije, u gradu Rijeci i njegovu kotaru politički okršaji bili su izrazito snažni. Više u: Lukežić, Riječki kvartet, 45-51, 71-83; Milan Marjanović, „Rijeka od 1860. do 1918.”, u: Rijeka: geografija - etnologija - ekonomija - saobraćaj - povijest - kultura. Zbornik, ur. Jakša Ravlić (Zagreb: Matica hrvatska, 1953), 215-221.

10 Sirotković je utvrdio da su kandidate za narodne zastupnike uglavnom predlagali ad hoc stvoreni odbori utjecajnih građana određene županije, kotara ili grada, a u najvećem broju izbornih jedinica predloženi kandidati uopće nisu imali protukandidata. Čini se da je slična situacija bila i u Riječkoj županiji. Sirotković, „Izborni red”, 237.

11 HR-HDA-99-RŽ, kut. 40, br. 233, br. 255, br. 346/ž.r.861; „Prva skupština riečke županie”, Pozor, br. 49, 28. 2. 1861., 111. Slično je bilo i u drugim županijama, pa je zagrebački odbor, koji se sastao 24. ožujka, u novinama preporučio kandidate za kotareve pojedinih gradova i županije. Tako je npr. glasačima jaskanskoga kotara bilo preporučeno da glasaju za Tomislava Cuculića. „Proglas”, Pozor, br. 73, 29. 3. 1861., 161. 
izbornici birali svojega zastupnika. ${ }^{12} \mathrm{U}$ gradu Rijeci neprestano su se događali politički nemiri, a snažna politička propaganda provodila se u talijanskom tisku i drugim oblicima djelovanja, ali na županiju oni, čini se, nisu imali snažnijega utjecaja kao što su to imali nešto kasnije, pred Nagodbu. ${ }^{13}$

Izbor zastupnika za Hrvatski sabor na području Riječke županije ${ }^{14}$ najranije je proveden u čabarskom kotaru. Sedam sudčija već je 24 . ožujka jednoglasno izabralo kotarskoga suca Tomislava Padavića ${ }^{15}$ za saborskoga zastupnika, s tim da je on izbor i nadzirao. To je moglo prouzrokovati problem zbog „sukoba interesa”, ali Riječka županija taj izbor nije prihvatila iz drugoga razloga. Naime, Padavić je dobio informaciju da njegov izbor nije valjan jer je obavljen prije nego što je stigao nalog da se provede i zato što je županijska skupština tvrdila da županijski činovnici takvu čast ne smiju primiti. Prema izvješću objavljenom u novinama, čini se da Riječka županija zaista nije prihvatila Padavićev izbor zbog toga što je obavljen prerano: „Dočim je gospodin sudac u Čabru držao izbor zastupnika za sabor prije, nego li je na to bio ovlašćen i pozvan po skupštini, a javio, da je on izabran, i da je već otišao preko Gradca u Zagreb, to se njegov izbor smatra ništetnim [...]"16 Županija je odredila da se izbor mora ponoviti i o tome obavijestiti županijsku skupštinu. Novi izbor održan je tek 8. travnja jer je Padavić zbog osobnih poslova bio na putu, a uspio se vratiti tek 7. travnja. Prilikom izbora utvrđeno je da nije točna tvrdnja da županijski činovnici ne mogu biti zastupnici na Saboru. Zapravo je zastupstvo županijskih činovnika na Saboru ograničavala sama županija odlukom da se nijedan županijski časnik ne može udaljiti iz županije bez dozvole županijske skupštine ili velikoga župana, ali ipak nijednom izabranom zastupniku nije zabranjen odlazak na saborsko zasjedanje. ${ }^{17}$ Izbornici čabarskoga kotara ponovno su jednoglasno za svojega zastupnika izabrali Padavića. Naime, izbornici su izjavili da nemaju bolju osobu kojoj bi dali povjerenje od gospodina Padavića, a nekoga nepoznatog ne žele jer smatraju da neće moći zastupati njihove interese. Taj su izbor još jednom pismeno potvrdili i sami izbornici u obraćanju velikom županu, naglasivši za Padavića: „[...] u njemu jedi-

\footnotetext{
12 Ante Starčević, Nekolike uspomene (Zagreb, 1870), 6.

13 Usp. Maja Polić, „Izvješće župana i privremenog upravitelja Riječke županije I. Vončine 17. lipnja 1867. kr. povjereniku E. Csehu za Rijeku, Bakar itd. o mađaronskim izgredima”, Vjesnik Državnog arhiva u Rijeci (Rijeka) (2003-2004), br. 45-46: 171-184; Maja Polić, „Mađaronski izgredi u Rijeci i bakarskome zaleđu uoči Hrvatsko-ugarske nagodbe 1868. godine”, Bakarski zbornik 9 (2004): 19-29 (9-33).

14 U dokumentima Riječke županije nije sačuvan cijeli izborni postupak, nije zabilježeno kako se provodio izbor birača po sudčijama, kako su formirani i tko je činio županijski izborni odbor i kotarsko izborno povjerenstvo. O tome: Sirotković, „Izborni red”, 228-231.

${ }_{15}$ Padavić je bio istaknuti narodnjak, ilirac. U Trstu je djelovao kao jedan od pokretača prvoga hrvatskog lista Naša sloga (1870.). Polić, „Izvješće župana”, 174.
}

16 „Županijske skupštine. Na Rieci, 4. travnja”, Pozor, br. 81, 9. 4. 1861., 177.

17 „Županijske skupštine. Na Rieci, 4. travnja”, Pozor, br. 81, 9. 4. 1861., 177-178. 
nom cĕlo naše povierenje imamo, da će on nas poznajući najbolje ovdašnje naše okolnosti, u svakom smislu tako zastupati, da gojimo nadu kroz njega postići ono što narod želi, jer on jedini potanko naše tegobe poznade, a drugim sposobnim licam kojimi naš položaj i zahtievanja naroda poznata nisu, oto velevažno poslanstvo, nipošto povjeriti nemožemo."18 Prilikom novoga izbora nadzor je obavljao županijski pristav Ferdinand Šlajmer, što je cijelom procesu dalo pravovaljanost, pa ga je Riječka županija na kraju prihvatila. Problem u izbornoj proceduri u čabarskom kotaru ležao je i u tome što je pri prvom izboru sudac Padavić izbor i nadzirao, a to je moglo izazvati sumnju u to je li izbor proveden slobodnom voljom birača. Na Saboru se i jest pojavila sumnja protiv njegova izbora prilikom verifikacije jer nije predao izborni zapisnik, nego samo punomoć koju su mu 8. travnja izdali birači čabarskoga kotara, a iz nje se nije moglo razabrati je li izbor proveden po $\$ 6$., točki c, privremenoga izbornog reda, odnosno je li poduzet pod nadzorom tamošnjega županijskog poglavarstva. Sumnja je ubrzo razriješena jer je pristigla službena svjedodžba Ferdinanda Šlajmera, koju je izdao 10. travnja, a u kojoj svjedoči da je redoviti izbor obavljen u njegovoj nazočnosti. Verifikacijski odbor zato je predložio da se Padavićev izbor prizna kao pravilan. ${ }^{19}$ Unatoč tome što je Riječka županija na kraju priznala njegov izbor kao pravovaljan, Padavić se prije odlaska na Sabor morao obratiti velikom županu da mu dopusti da napusti županiju uvjeravajući ga da njegovom odsutnošću neće biti nanesena šteta uredovanju u kotaru jer će ga zamijeniti pristav Šlajmer, za kojega je jamčio da će vješto, pravedno i zakonito upravljati kotarom. ${ }^{20}$ Padavić je prisustvovao radu Sabora od njegova početka, što znači da nije bilo problema oko dobivanja dopuštenja od velikoga župana.

Izbor zastupnika za vrbovski kotar proveden je 3. travnja, pri čemu je jednoglasno izabran Juro (Đuro) Petrović, povjerenik sigurnosti. No 10. travnja Đ. Petrović zahvalio se na izboru te je istoga dana organiziran novi izbor. Tom je prilikom za zastupnika izabran Gervasio Petrović, gomirski arhimandrit, koji je tu čast i prihvatio. Prilikom verifikacije saborskih članova 5. saborski odbor utvrdio je da je G. Petrović izabran i za zastupnika prečasnoga konzistorija gornjokarlovačkoga, a s obzirom na to da nije postojala mogućnost da netko zastupa istovremeno i kotar i korporaciju, predloženo mu je neka odabere jedno zastupstvo da bi se za drugo obavio novi izbor ili pozvao imenovani zamjenik. Gervasio Petrović odlučio je zastupati vrbovski kotar. ${ }^{21}$

\footnotetext{
18 HR-HDA-99-RŽ, kut. 40, br. 227, br. 340, br. 443/ž.r.861.

19 Dnevnik Sabora trojedne kraljevine Dalmacije, Hrvatske i Slavonije držana u glavnom gradu Zagrebu god. 1861. (dalje: Dnevnik Sabora 1861.) (Zagreb, 1862), 40.

20 HR-HDA-99-RZ̆, kut. 40, br. 227, br. 332, br. 333, br. 340.

${ }^{21}$ HR-HDA-99-RŽ, kut. 40, br. 307, br. 401; Dnevnik Sabora 1861., 40-41, 46.
} 
Za zastupnika delničkoga kotara izabran je Faustin Suppé i čini se da je taj izbor proveden bez ikakvih poteškoća. ${ }^{22}$

U vinodolskom kotaru situacija je pak bila nešto složenija. Naime, Riječka županija smatrala je da vinodolski kotar treba podijeliti na dva dijela/kotara, vinodolski i grobničko-hreljinski, radi lakše uprave, argumentirajući to podatkom da u njemu ima preko trideset tisuća duša koje raštrkano žive po vrletima toga kotara. O tome je obavijestila Dikasterij jer je posljedica te odluke bio zahtjev da se tom kotaru omogući slanje dvojice zastupnika na predstojeći Sabor, a ne jednoga kako je bilo određeno privremenim izbornim redom. U međuvremenu je 1. i 2. travnja provela izbor za vinodolski kotar iz kojega su bile posebno izdvojene i općine Novi i Bribir, pri čemu je zastupnikom Novoga postao riječki podžupan Ivan Vončina, a zastupnikom Bribira Jakin (Jaćim) Pavletić, ${ }^{23}$ kojega je u slučaju spriječenosti trebao mijenjati Antun Jakić. Za zastupnika ostalih vinodolskih općina izabran je Eugen Kvaternik. Za grobničko-hreljinski kotar izbori su održani 2. travnja u Bakru i na njima je jednoglasno izabran Ante Starčević, veliki bilježnik Riječke županije. ${ }^{24}$ Dikasterij se proglasio nenadležnim odobriti spomenute promjene i uputio je županiju na to da se promjene moraju provesti ustavnim putem, odnosno putem Sabora i uz odobrenje Njegova Veličanstva, ali je ipak Riječku županiju i opomenuo da se mora držati naputka o uređenju municipija i o privremenom izbornom redu. ${ }^{25}$ Riječka županija poslušala je naloženo te odlučila da se za vinodolsko okružje, tj. kotar ipak bira jedan saborski zastupnik, a situacija im je bila olakšana i odlukom E. Kvaternika, koji se zahvalio na izboru za zastupnika vinodolskih općina. Novi izbor održan je 11. travnja u Triblju, pri čemu je sama županija, odnosno njezin podžupan dao i preporuku da se za vinodolskoga

22 Faustin Suppé (1813. - 1868.), riječki odvjetnik, političar i istaknuti hrvatski domorodac. Utemeljitelj i dugogodišnji predsjednik Narodne čitaonice riečke, riječki gradski i županijski činovnik i saborski zastupnik. Više o njemu u: Lukežić, Riječki kvartet, 7, 11-64; „Brzojavna viest Pozorova. Iz Rieke, 12. travnja", Pozor, br. 85, 13. 4. 1861., 187.

23 Općine Bribir i Novi bile su 1848. dio slobodnoga kotara primorskog, koji je na Saboru 1848. imao dva zastupnika. No taj je kotar rasformiran, a Novi i Bribir dobili su prema izbornom redu 1861. pravo slati svaki po jednoga zastupnika. Sirotković, „Izborni red”, 222.

${ }^{24}$ HR-HDA-99-RZ̆, kut. 40, br. 255; „Brzojavne viesti Pozorove. Iz Rieke, 3. travnja”, Pozor, br. 77, 4. 4. 1861., 169; Sirotković, „Izborni red”, 220. Tri povlaštena trgovišta, Mrkopalj, Ravna Gora i Vrbovsko, također su tražila da im se odobri slanje trojice zastupnika na Sabor jer je samo Mrkopalj imao gotovo 3000 stanovnika, što je prema izbornom redu bila granica koja je jamčila jednoga zastupnika. Izbor zastupnika za trgovišta Mrkopalj, Ravna Gora i Vrbovsko držao je 7. travnja kotarski sudac Erazmo Barčić, za zastupnika je izabran gospodin Tomo (Tomislav) Cuculić iz Zagreba, a za njegova zamjenika Tone (Antun) Cuculić iz Mrkoplja. Odmah je proveden i izbor zastupnika u slučaju da ta tri trgovišta dobiju pravo samostalnoga zastupstva na Saboru te je za Ravnu Goru zastupnikom izabran kanonik Franjo Rački, a za Vrbovsko odvjetnik Lavoslav Šram. Saborski odbor za ovjerovljenje odobrio je zahtjev da svaka općina šalje jednoga zastupnika te su od početka svibnja one na Saboru zastupane napose. HR-HDA-99-RZ̆, kut. 40, br. 339, br. 482, kut. 50, br. 49/v.sk; „Sabor trojedne kraljevine (Deveta sjednica dne 29. travnja)", Pozor, br. 99, 30. 4. 1861., 219.

25 HR-HDA-99-RŽ, kut. 40, br. 233, kut. 50, br. 50/v.sk. 
zastupnika izabere I. Mažuranić, a kao njegov zamjenik dr. A. Starčević. U svojim Uspomenama Starčević je negativno opisao reakciju u Riječkoj županiji na kandidaturu I. Mažuranića za njezina saborskoga zastupnika: „Za buduće bo poklisare iz opsega županie rečke budu od stanovite strane predloženi: Bužan, g. I. Mažuranić, i još jedan [...]. Na ta imena biaše mermljanja, nad onim Mažuranića biaše i podsmehavanja dervena." ${ }^{26}$ Ipak, Mažuranićev izbor zastupali su riječki župan Zmaić i podžupan Vončina te je on i izabran za vinodolskoga zastupnika, a Starčević za njegova zamjenika. ${ }^{27}$

Unatoč tome što je bio prihvaćen nalog Dikasterija da se Riječka županija mora držati privremenoga izbornog reda, nije se odustalo od ideje da vinodolski kotar zastupaju dva zastupnika na Saboru te je ostalim zastupnicima Riječke županije naloženo da odmah zatraže od Sabora neka dopusti grobničko-hreljinskom kotaru da pošalje svojega zastupnika. Oni su to učinili već na saborskoj sjednici 26. travnja, a Vončina je predao i pismenu molbu verifikacijskom odboru. ${ }^{28}$

Prilikom verifikacije saborskih članova četvrti verifikacijski odbor utvrdio je da je Mažuranić izabran u dvama kotarevima, u kotaru vinodolskom i u općinama Cvetković, Draganić i Petrovina, te mu je preporučeno da, s obzirom na odredbe privremenoga izbornog reda prema kojima nitko ne može istovremeno zastupati dva kotara, odabere koji će kotar zastupati da bi se za preostali proveli novi izbori ili pozvali već određeni zamjenici. U vinodolskom kotaru, kako je rečeno, za zamjenika mu je bio određen Starčević, a u spomenutim trgovištima Adolf Veber. Mažuranić je odbio zastupati povlaštena trgovišta i odlučio se za vinodolski kotar. ${ }^{29}$ Usto je Sabor priznao podjelu vinodolskoga kotara na dva dijela, vinodolski i grobničko-hreljinski kotar, te se Starčević 27. travnja obratio županiji sa zahtjevom da mu odobri odlazak u Zagreb. Svoje bilježničke poslove Starčević je ostavio s punim povjerenjem dr. Marijanu Derenčinu, jamčeći da će ih on voditi i držati u najboljem redu. Tom se prilikom također izjasnio da će se držati svih naputaka koje je županijska skupština dala poklisarima te izjavio: „Naputci, što ih je slavna skupština županijskim poklisarima dala, za me su sveti, i bilo što mu drago, ja neću od njih ni za stopu odstupiti." ${ }^{\text {30 }}$

\footnotetext{
26 Starčević, Nekolike uspomene, 6.

27 HR-HDA-99-RŽ, kut. 40, br. 233, br. 255, br. 346/ž.r.861; „Bèrzojavne i najnovije viesti. Iz Rieke, 3. travnja”, Narodne novine (Zagreb), br. 78, 5. 4. 1861., 238; „Brzojavna viest Pozorova. Iz Rieke, 12. travnja”, Pozor, br. 85, 13. 4. 1861., 187. Vidi i: Starčević, Nekolike uspomene, 6-7.

28 U Naputku Riječke županije njezinim je zastupnicima naloženo da i za trgovišta Mrkopalj, Ravna Gora i Vrbovsko traže od Sabora da im se dopusti slanje po jednoga zastupnika za svako. HR-HDA99-RŽ, kut. 50, br. 86/v.sk; „Naputak”, Pozor, br. 81, 9. 4. 1861., 178; „Županijske skupštine. Na Rieci, 4. travnja”, Pozor, br. 81, 9. 4. 1861., 178; Dnevnik Sabora 1861., 46; Starčević, Nekolike uspomene, 7.

29 Dnevnik Sabora 1861., 40-41, 46.

${ }^{30}$ HR-HDA-99-RZ̆, kut. 40, br. 443/861.
} 
Iz prikaza izbora vidljivo je da su zastupnici Riječke županije uglavnom birani među županijskim i gradskim činovnicima (Padavić, Suppé, Starčević).

\section{Saborsko djelovanje izabranih zastupnika Riječke županije}

Zanimljivo je da je upravo Starčević sastavio Naputak, a Riječka županija objavila ga je već 4 . travnja naznačujući u njemu smjer koji su njezini zastupnici trebali zastupati u državnopravnim pitanjima, ali i lokalnu problematiku koju su trebali staviti na dnevni red saborskih sjednica. ${ }^{31} \mathrm{U}$ svibnju, tijekom saborskoga zasjedanja, Riječka županija uputila je još jedan naputak zastupnicima sa svojega područja, ne samo županijskim nego i onima koji su zastupali trgovišta i općine s njezina područja, te je posebno naznačeno da je on upućen Vončini, Pavletiću, Suppéu Petroviću, Padaviću, Cuculiću te Starčeviću, pa je vjerojatno da se i prvi odnosio na sve njih. ${ }^{32}$ Zanimljivo, taj naputak nije upućen Mažuraniću, no treba uzeti u obzir da on nije bio samo narodni zastupnik nego i predsjednik privremenoga Hrvatsko-slavonskog dikasterija, pa je njegova uloga u saborskom radu bila dvojaka, a postojalo je i određeno nepovjerenje prema njemu, kako je spomenuto. $^{33}$

Naputke svojim zastupnicima izdavale su i druge županije, a prema izbornom redu, čl. 4., $\$ 10$., to je bilo dopušteno te su zastupnici glasali „[...] po svojem unutarnjem osviedočenju u svakom onom slučaju, gdie osobitog naloga imali nebi" ${ }^{34}$ U Naputku je na prvome mjestu istaknuta ideja da se zastupnici moraju zalagati za dobrobit naroda: „[... treba se svojski zauzeti da se nužde naroda blagostanjem nadomeste, i da narod na stazi napredovanja nenalazi zaprĕkah nego sve to više polakšicah.” Naputak se zatim bavi glavnim pitanjima zbog kojih je Sabor sazvan, a to su pitanja državnopravne naravi: položaj Trojedne Kraljevine i njezin odnos prema Austriji i Ugarskoj. Prema Naputku, zastupnici moraju nastojati da se vrate ustav i cjelokupnost Trojedne Kraljevine. To je bio cilj svih hrvatskih političkih aktera 1861., ali su nudili različita rješenja kako ga postići. Riječka županija svoje je zastupnike uputila neka se založe za to da se Kraljevina Hrvatska upotpuni s Dalmacijom s otocima, da joj se vrati Međimurje, a Granica da se ukine. Posebno se tražilo da se grad Senj, koji je tada još bio u sastavu Vojne krajine, pripoji Riječkoj županiji, i to bez pitanja vojne vlasti. Ideju obnove cjelokupnosti hrvatskih zemalja nitko od izabranih zastupnika Riječke županije nije

\footnotetext{
31 Markus, Predstavke županija i gradova Banske Hrvatske, 171-172.

32 HR-HDA-99-RZ̆, kut. 50, br. 86/v.sk.

33 Jaroslav Šidak, „Ivan Mažuranić kao političar”, u: Studije iz hrvatske povijesti XIX. stoljeća (Zagreb: Sveučilište u Zagrebu, Institut za hrvatsku povijest, 1973), 294-298; Starčević, Nekolike uspome$n e, 6$.

${ }^{34}$ HR-HDA-99-RŽ, kut. 40, br. 58. Praksa davanja naputaka zastupnicima naziva se imperativni mandat. Sirotković, „Izborni red”, 225.
} 
dovodio u pitanje, a T. Cuculić, koji nije bio riječki županijski zastupnik, ali je kao zastupnik dolazio s područja Riječke županije, bio je i za to da se i u inauguralnoj zavjernici potanko naznači cjelokupnost domovine, i to s Dalmacijom..$^{35} \mathrm{U}$ pitanju Vojne krajine, Starčević je upravo u tom naputku iznio nepovjerenje prema krajiškim zastupnicima: „Ako bi poklisari iz granice, prie nego-li se granica razvérže već na ovaj sabor došli [...] sabor mora imati dovoljno jamstvo, dotično dokaz, da se izbor onih poklisarah obavio bez svakoga upliva vojničke oblasti." To su mu nepovjerenje na saborskom zasjedanju politički protivnici predbacivali, no unatoč iznesenoj sumnji prema krajiškim zastupnicima, Starčević nije dvojio o priključenju Vojne krajine Trojednici. ${ }^{36}$

Što se tiče odnosa prema Austriji, zastupnicima Riječke županije dane su upute da za austrijski sabor nikoga ne biraju, a ako tko od njih bude izabran za taj sabor, neka na njega ne ide. Odlazak na austrijski sabor, točnije u Carevinsko vijeće, značio je djelomično odustajanje od ustavnosti, koja je Hrvatskoj (i Ugarskoj) jamčila određenu samostalnost, i zbog toga odlazak u Beč nije bio prihvatljiv. Protiv slanja zastupnika u Carevinsko vijeće izjasnili su se svi riječki zastupnici, ali situaciju je komplicirala izjava Maksa Price, koju je poduprla manjina osrednjega odbora, a nju su činili prvaci Narodne stranke, među kojima i I. Mažuranić. Prica je izjavio da se izbor zastupnika u Carevinsko vijeće odbija, ali da treba izjaviti da postoje zajednički interesi između Trojedne Kraljevine i ostalih naroda i zemalja Monarhije. ${ }^{37}$ Od riječkih zastupnika bili su za to da se o Pricinoj izjavi raspravlja Vončina, Cuculić te Zoričić, koji je mijenjao Suppéa, koji su ju vjerojatno bili spremni i podržati. Protiv su bili Starčević, koji je inače bio žestoki protivnik Austrije, Petrović i Pavletić, a Padavić je već bio napustio Sabor, a njegova zamjena još nije bila prihvaćena. ${ }^{38}$ Pricinu izjavu nije prihvatila većina Sabora, pa se o njoj nije raspravljalo, ali ona je pokazala podvojenost u redovima Narodne stranke glede političkoga smjera kojim je trebalo ići u osiguravanju cjelovitosti i ustavnosti Trojedne Kraljevine, pa tako i među izabranim zastupnicima s područja Riječke županije.

U odnosu prema Ugarskoj u Naputku stoji da treba zagovarati jedinstvo u osobi vladara, to jest personalnu uniju, a za ostale odnose da se rješavaju preko povjerenika hrvatskoga i ugarskoga sabora, čija bi rješenja zatim sabori trebali potvrditi. I u toj točki do izražaja dolazi želja za očuvanjem samostalnosti utemeljene u hrvatskoj ustavnosti. Zastupnici Riječke županije nisu se držali ni te upute. Većina

\footnotetext{
${ }_{35}$ Dnevnik Sabora 1861., 517.

36 Vidljivo je to i iz predstavki Riječke županije koje je kao njezin veliki bilježnik sastavljao Starčević. Vidi: Markus, Predstavke županija i gradova Banske Hrvatske, 142-145, 155-157.

37 Mirjana Gross, Prema hrvatskom građanskom društvu. Društveni razvoj u civilnoj Hrvatskoj i Slavoniji šezdesetih i sedamdesetih godina 19. stoljeća (Zagreb: Globus nakladni zavod, 1992), 137. O Mažuranićevoj ulozi više u: Šidak, „Ivan Mažuranić kao političar”, 297-299.

38 Dnevnik Sabora 1861., 529, 597, 609-610.
} 
ih se izrazila za prijedlog osrednjega odbora u kojem se izražava sklonost obnovi državnopravnoga saveza s Ugarskom, ali uz određene uvjete, tj. za znameniti čl. 42., čiji je koncept oblikovao sam Mažuranić. Jedino je Starčević, podržavši prijedlog E. Kvaternika, bio usklađen sa svojom uputom iznesenom u Naputku. ${ }^{39}$

U Naputku su se zagovarale i neke promjene u skladu s vremenom, poput isključenja članova Banskoga stola iz saborskoga rada. Zahtjev da se sloboda luka protegne na sve Hrvatsko primorje te da se za njega ustanovi posebna pomorska oblast također se nalazio u Naputku, a izabranim zastupnicima s područja Riječke županije tijekom zasjedanja stigla je i uputa da protestiraju protiv odluke bečke vlade kojom se obvezala Društvu južnih željeznica da će svakom drugom društvu uskratiti dozvolu za vođenje željeznice k moru, ako je ta odluka istinita, jer će voditi propasti trgovine u Riječkoj županiji i uopće naštetiti županiji. ${ }^{40}$

Sve te točke Naputka imale su za cilj osigurati ustavnost i cjelokupnost Trojedne Kraljevine u kojoj bi se slobodno i uspješno razvijala i Riječka županija na dobrobit svih svojih stanovnika. No, već je T. Markus zaključio da predstavke koje je Starčević sastavljao kao veliki bilježnik Riječke županije nisu njezino službeno stajalište, što je vidljivo i iz reakcije izabranih zastupnika Riječke županije na pojedine točke Naputka kad nisu glasali u skladu s njima, ali ih je prihvaćala vjerojatno zato što je u njima snažno isticana hrvatska državnost i neprekinutost hrvatskih prava tijekom stoljeća. ${ }^{41}$ Iz glasanja o najvažnijim saborskim pitanjima, dakle o odnosu prema Ugarskoj i Austriji, vidljivo je da se upravo među riječkim zastupnicima stvaraju zametci novih političkih stranaka koje će na političku scenu stupiti u nadolazećem razdoblju.

Izabrani zastupnici s područja Riječke županije sudjelovali su u brojnim saborskim raspravama te bili angažirani u različitim saborskim odborima. Kad se raspravljalo o odluci grada Rijeke da neće poslati svoje zastupnike na Hrvatski sabor, pojedini izabrani zastupnici Riječke županije nastojali su upozoriti Sabor na razdraženost protiv Hrvata u Rijeci, za što nisu optuživali samo strance koji su svojom propagandom bunili narod nego i nedovoljan angažman domaće vlade u obrani prava hrvatskoga naroda, te su tražili poduzimanje određenih mjera. Mažuranić je čak bio predložio da Sabor zahtijeva da se kao pravni temelj za pripadnost Rijeke Trojednici ozakoni patent od 7. travnja 1850., u kojem je stajalo da Kraljevina Hrvatska i Slavonija zajedno s Hrvatskim primorjem i gradom Rijekom ima posve nezavisno zemaljsko upravljanje od Ugarske. No taj prijedlog nije prihvaćen. O položaju grada Rijeke raspravljalo se u nekoliko navrata. Zastupnici

39 Gross, Prema hrvatskom građanskom društvu, 132-134; Šidak, „Ivan Mažuranić kao političar”, 296; Dnevnik Sabora 1861., 171-172, 358, 384, 400; Perić, Hrvatski državni sabor, 279-282; Pavo Barišić, ur., Ante Starčević. Izabrani politički spisi (Zagreb: Golden marketing; Narodne novine, 1999), 18, 48-65.

40 HR-HDA-99-RŽ, kut. 50, br. 86/v.sk.

${ }^{41}$ Markus, Predstavke županija i gradova Banske Hrvatske, 38. 
s područja Riječke županije tek su povremeno sudjelovali u tim raspravama, a najviše se istaknuo Vončina, koji je inzistirao da se u službenu uporabu u gradu i kotaru Rijeka uvede hrvatski jezik, a protivio se talijanskom. No, po tom je pitanju u Saboru ipak prihvaćen prijedlog da se u gradu Rijeci vodi računa o talijanskom jeziku i da se dopusti njegova uporaba. Kao konačan rezultat rasprava o gradu Rijeci donesen je zakonski članak 65., kojim je grad i kotar Rijeka proglašen sastavnim dijelom Trojednoj Kraljevini, a Riječka županija ozakonjena. Ipak, taj zakonski članak nije dobio kraljevu sankciju, pa je pitanje grada Rijeke ostalo otvoreno. ${ }^{42}$

Vončina i Pavletić također su podnijeli neke važne prijedloge o kojima je Sabor trebao raspravljati. Vončina je tako podnio prijedlog o ustrojstvu Sabora, a iz Pavletićeva pera proizašla su čak tri važna prijedloga: o ustrojavanju zemaljske vlade, o ustrojavanju zemaljskoga sabora i o svojstvima potrebnim za postignuće sudačke vlasti, za koje je podnio zahtjev da se uvrste u saborsku raspravu, što je i prihvaćeno. ${ }^{43}$ Vončina i Cuculić sudjelovali su u radu brojnih saborskih odbora, napose potkraj zasjedanja, kad su se donosili različiti zakonski prijedlozi (o uređenju municipija, o narodnom jeziku i dr.). Time se njihov doprinos zakonodavnom uređenju hrvatskih oblasti može ocijeniti kao izniman.

Izabrani riječki zastupnici u svojem su saborskom djelovanju nastojali na dnevni red rasprava staviti i neka pitanja važna za njihovu lokalnu sredinu. $U$ tome se najviše istaknuo zastupnik čabarskoga kotara Padavić. Na njegov prijedlog $\mathrm{u}$ Saboru se čitala molba Čabrana u kojoj traže da im se vrati staro pravo drvarenja te da im se dopusti da to pravo koriste besplatno u vlastelinskim šumama. Molba je poslana odboru koji je rješavao molbe. No, pred tim odborom našlo se još nekoliko molbi čabarskih žitelja, poput molbe čabarske sudčije da se nastavi gradnja ceste iz Čabra preko Praga do Prezida, zatim molba čabarskoga kotara da se vlastelinstvo prisili da im daje gorivo i građevno drvo za zidanje i mostove, da se spriječe štete u tamošnjim šumama, čiji pravni status još nije riješen, a koje nanose trgovački poduzetnici, da se općinama vrati 4.000 forinti što ih je bivše zastupništvo općina darovalo za gospodarsku učionu u Križevcima, te da se umanji carski porez. Sve je te molbe odbor za molbe odlučio vratiti županiji s obrazloženjem da njihovo rješavanje ne spada u djelokrug Sabora. ${ }^{44}$

Možda je upravo takav odgovor odbora za molbe bio poticaj da Padavić, uvidjevši da na Saboru ne može mnogo učiniti za svoj kotar, zatraži razrješenje od zastupstva. On je već 7 . lipnja podnio molbu za razrješenje s obrazloženjem da ga župa-

${ }_{42}$ Dnevnik Sabora 1861., 57, 618, 624-625, 631, 650-651; Mirjana Gross, „Dvadeset godina bijesa i očaja ili borba za Rijeku od 1861. do 1881.”, Dometi 20 (1987), br. 4: 185-187; Marjanović, „Rijeka od 1860. do 1868.", 220-222.

43 Dnevnik Sabora 1861., 148-149, 156; Perić, Hrvatski državni sabor, 247, 249.

${ }^{44}$ Dnevnik Sabora 1861., 146, 157, 550. 
nija zove u kotar, tj. da mora obavljati svoje kotarske poslove. Svoju molbu ubrzo je, navodno, usmeno opozvao jer je dobio dopuštenje županije da i dalje sudjeluje $\mathrm{u}$ radu Sabora. ${ }^{45}$ No već je u srpnju ponovno odustao od svojega mandata, ali saborsko zasjedanje nije mogao napustiti dok u Sabor ne dođe njegov zamjenik. Zbog toga je za čabarski kotar proveden novi izbor, pri čemu su izbornici za svojega zastupnika izabrali Eugena Kvaternika. Kvaternik je u Saboru sjedio kao ribnički zastupnik, ali se baš u tom trenutku u saboru našlo pismo žitelja ribničkoga kotara u kojem su iznijeli zahtjev za opoziv Kvaternika kao njihova zastupnika jer nisu bili zadovoljni njegovim izjavama vezanim uz rješavanje državnopravnih odnosa između Trojedne Kraljevine i Kraljevine Ugarske. ${ }^{46}$ Kvaternik ipak nije mogao biti opozvan, pa posljedično nije mogao preuzeti zastupstvo čabarskoga kotara te je u njemu morao biti proveden novi izbor, na što su izbornici čabarskoga kotara i županija bili upozoreni. Vjerojatno je situacija u kojoj se činilo da će Kvaternik uskoro ostati bez zastupstva, a ne nepoznavanje izbornoga reda, bila razlog da su žitelji čabarskoga kotara izabrali Kvaternika za svojega zastupnika. Napokon su 18. srpnja dobili nalog da moraju provesti još jedan izbor. Tada je za čabarskoga zastupnika 30. srpnja izabran, odnosno odobren odvjetnik iz Zagreba Gjuro (Juraj) Križanić, koji je to zastupstvo i prihvatio. Padavić je tek tada mogao položiti svoj mandat, a to je učinio 5. kolovoza i zatim se vratio u svoj kotar. Istoga dana na Saboru je čitan izborni zapisnik za Križanića i poslan verifikacijskom odboru na potvrdu. Izborni zapisnik prihvaćen je 14. rujna te je tada Križanić i verificiran za saborskoga zastupnika. ${ }^{47}$ Nije jasno kako je pala odluka da Juraj Križanić uopće bude predložen za kandidata za zastupnika čabarskoga kotara. U Saboru je pak aktivno sudjelovao u raspravama već od kolovoza, pri čemu je posebno dolazilo do izražaja njegovo pravno iskustvo, npr. u raspravi o zakonskom članku o zločinu izdaje domovine, o ukidanju Vojne krajine ili gradnji sisačkoga mosta. Sudjelovao je i u raspravama o državnopravnim pitanjima, zalažući se za to da se ona ne mogu rješavati bez krajišnika, te u raspravama o uređenju županija i prava zastupstva. Od tema vezanih uz županiju koju je zastupao pročitao je izvješće peticijskoga odbora koje se ticalo općina Kraljevica, Kostrena, Draga, Trsat i Piket, koje su tražile da se odijele od grada i kotara Bakar te pripoje Riječkoj županiji. ${ }^{48}$ Bio je član saborskoga financijskog i sudbenog odbora. ${ }^{49}$

Faustin Suppé također je početkom lipnja zatražio dvotjedni dopust, što mu je Sabor dopustio, ali je već 13. lipnja 1861. obavijestio riječkoga velikog župana da je zbog bolesti prisiljen napustiti Sabor, a zbog liječenja će morati biti duže odsutan, pa se odlučio odreći zastupstva. Zamolio je zato velikoga župana da čim pri-

\footnotetext{
45 Dnevnik Sabora 1861., 157.

46 Dnevnik Sabora 1861., 364.

47 HR-HDA-99-RŽ, kut. 42, br. 1079, br. 1202, br. 1286; Dnevnik Sabora 1861., 609, 819.

48 Dnevnik Sabora 1861., 626-627, 630, 637, 674-675, 840, 895-896.

49 Dnevnik Sabora 1861., 889.
} 
je naloži velikom sudcu delničkoga kotara Mati Matkoviću da organizira izbor njegova zamjenika/namjesnika, koji će ga zastupati u Saboru dok je on spriječen. Izbor je proveden 22. lipnja te je umjesto Suppéa zastupnikom za delnički kotar izabran Antun Zoričić, zagrebački odvjetnik, koji nije imao neku aktivniju ulogu u saborskim raspravama. ${ }^{50}$

\section{Zaključak}

Prvi parlamentarni izbori na području Riječke županije održani su krajem ožujka i početkom travnja 1861. godine. Zastupnici su birani na redovnim, ali i na ponovljenim izborima. Ponovljeni izbori bili su rezultat pogrešaka u proceduri, težnje da županija izabere što više zastupnika za Sabor od kojega se mnogo očekivalo, ali i odustajanja pojedinih izabranih zastupnika od saborskoga mandata. Od pet zastupnika koliko ih je Riječka županija birala za Sabor, dvojica su tijekom saborskoga zasjedanja zatražila razrješenje od zastupstva, a zahtjev su obrazložili različitim razlozima. Zastupnike koji su napustili Sabor (Padavić, Suppé), a bili su s područja Riječke županije, zamijenila su dvojica zagrebačkih odvjetnika. Možemo samo pretpostaviti da je odlučeno da se za nove zastupnike izaberu osobe koje su bile s područja grada Zagreba ne bi li se smanjili troškovi koje je županija imala zbog slanja svojih zastupnika na Sabor, jer je i Sabor zasjedao u Zagrebu. Od izabranih riječkih zastupnika najdublji trag u radu Sabora 1861. ostavili su svojim državnopravnim idejama Mažuranić i Starčević, ${ }^{51}$ a djelovanje ostalih može se ocijeniti kao vrlo umjereno. Zanimljivo je da je Riječka županija svoje naputke davala i drugim zastupnicima koji su dolazili s njezina područja (zastupnicima povlaštenih trgovišta i općina), nastojeći tako na Saboru snažnije promovirati ideje proizašle iz njezine županijske skupštine, ali pokazalo se da je u nekim važnim državnopravnim pitanjima i među izabranim riječkim zastupnicima postojala podvojenost, kao što je to bilo u raspravi o zajedničkim poslovima s Austrijom ili o odnosima s Ugarskom, iz čega se naziru zametci novih političkih stranaka koje će na političku scenu stupiti u nadolazećem razdoblju.

50 HR-HDA-99-RŽ, kut. 51, br. 53²/2/pr; Dnevnik Sabora 1861., 157, 351, 364, 684.

51 Šidak, „Ivan Mažuranić kao političar”, 296-299; Dragutin Pavličević, ur., Ivan Mažuranić. Izabrani politički spisi (Zagreb: Golden marketing; Narodne novine, 1999), 30-31. 


\section{Neobjavljeni izvori}

Hrvatska - Hrvatski državni arhiv, Zagreb - fond 99 - Riječka županija (HRHDA-99-R $\check{Z}$ ).

\section{Objavljeni izvori i literatura}

Barišić, Pavo, ur. Ante Starčević. Izabrani politički spisi. Zagreb: Golden marketing; Narodne novine, 1999.

Narodne novine (Zagreb), 1861.

Dnevnik Sabora trojedne kraljevine Dalmacije, Hrvatske i Slavonije držana u glavnom gradu Zagrebu god. 1861. Zagreb, 1862.

Gross, Mirjana. „Dvadeset godina bijesa i očaja ili borba za Rijeku od 1861. do 1881." Dometi 20 (1987), br. 4: 183-225.

Gross, Mirjana. Prema hrvatskom građanskom društvu. Društveni razvoj u civilnoj Hrvatskoj i Slavoniji šezdesetih i sedamdesetih godina 19. stoljeća. Zagreb: Globus nakladni zavod, 1992.

Hameršak, Filip, prir. Mali leksikon hrvatske pravne povijesti. Zagreb, 2013. Pristup ostvaren 12. 11. 2021. https://www.pravo.unizg.hr/_download/repository/ Mali_leksikon_hrvatske_pravne_povijesti\%5B1\%5D.pdf.

Hauptmann, Ferdinand. Rijeka: od rimske Tarsatike do Hrvatsko-ugarske nagodbe. Zagreb: Matica hrvatska, 1951.

Klen, Danilo, ur. Povijest Rijeke. Rijeka: Skupština općine Rijeka; Izdavački centar Rijeka, 1988.

Lukežić, Irvin. Riječki kvartet. Biblioteka časopisa Fluminensia, knj. 5. Rijeka: Filozofski fakultet Sveučilišta u Rijeci, 2008.

Marjanović, Milan. „Rijeka od 1860. do 1918.” U: Rijeka: geografija - etnologija ekonomija - saobraćaj - povijest - kultura. Zbornik, uredio Jakša Ravlić, 215-252. Zagreb: Matica hrvatska, 1953.

Markus, Tomislav. Predstavke županija i gradova Banske Hrvatske: izabrani dokumenti 1861. - 1867. Zagreb: Dom i svijet, 2002.

Pavličević, Dragutin. „Županije u Hrvatskoj i Slavoniji u prijelaznom razdoblju od 1848. do 1881." U: Hrvatske županije kroz stoljeća, uredio Ivo Goldstein, 71-97. Zagreb: Školska knjiga, 1996.

Pavličević, Dragutin, ur. Ivan Mažuranić. Izabrani politički spisi. Zagreb: Golden marketing; Narodne novine, 1999. 
Perić, Ivo. Hrvatski državni sabor 1848. - 2000., svezak 1: 1848. - 1867. Zagreb: Hrvatski državni sabor; Hrvatski institut za povijest; Dom i svijet, 2000.

Polić, Maja. „Mađaronski izgredi u Rijeci i bakarskome zaleđu uoči Hrvatsko-ugarske nagodbe 1868. godine”. Bakarski zbornik 9 (2004): 9-33.

Pozor (Zagreb), 1861.

Polić, Maja. „Izvješće župana i privremenog upravitelja Riječke županije I. Vončine 17. lipnja 1867. kr. povjereniku E. Csehu za Rijeku, Bakar itd. o mađaronskim izgredima”. Vjesnik Državnog arhiva u Rijeci (Rijeka) (2003-2004), br. 4546: 171-184.

Sirotković, Hodimir. „Izborni red za Sabor od 1861. godine i provođenje izbora”. Rad JAZU, knj. 47 (1967): 211-276.

Smrekar, Milan. Priručnik za političku upravnu službu u kraljevinah Hrvatskoj $i$ Slavoniji. Zagreb: Tiskom i nakladom Ignjata Granitza, 1899.

Starčević, Ante. Nekolike uspomene. Zagreb, 1870.

Šidak, Jaroslav. „Ivan Mažuranić kao političar”. U: Studije iz hrvatske povijesti XIX. stoljeća, 279-308. Zagreb: Sveučilište u Zagrebu, Institut za hrvatsku povijest, 1973. 


\section{Arijana Kolak Bošnjak*}

\section{Elections in the Rijeka County and Its Deputies to the Croatian Parliament of 1861}

\section{Summary}

The first parliamentary elections in the Rijeka County were held in 1861. Five deputies were to be elected, so this paper presents the election process in all five districts of the county. Deputies were elected in regular as well as repeated elections, which occurred due to certain doubts about the election procedure or the withdrawal of individual deputies from the parliamentary mandate. The author analyzes the activity of the elected representatives of the Rijeka County in the Parliament of 1861, i.e. their compliance with the Instruction issued by the County, which contained guidelines for their parliamentary activities as well as other parliamentary work. However, as the Rijeka County gave instructions to other representatives from its area as well, i.e. representatives of privileged marketplaces and municipalities, these have also been included in the analysis of parliamentary work and compliance with the Instruction of the Rijeka County.

Keywords: parliamentary elections, Croatian Parliament of 1861, Rijeka County, deputies

\footnotetext{
* Arijana Kolak Bošnjak, Croatian Institute of History, Opatička 10, 10000 Zagreb, Croatia, E-mail: akolak@isp.hr
} 